\title{
Chronicling Resistance while Cloistered: Overcoming Erasure, Omission, and Alienation in the Archive
}

\begin{abstract}
This paper examines the ways the Philadelphia-based Chronicling Resistance project is breaking down or reinforcing the silencing of historically marginalized populations in the archives and the ways the shuttering of archives during the coronavirus pandemic has affected those populations' access to and relationship with archival material. Initiated by the Philadelphia Area Consortium of Special Collections Libraries (PACSCL) in 2018, Chronicling Resistance has had two chief aims: to amplify stories of resistance in the archives and to help collect and preserve stories of today's acts of resistance. The global pandemic hit shortly after the project entered a pilot phase (February 2020) in which three individuals who identify as black and as cultural organizers began working as nontraditional archival research fellows in PACSCL institutions. The researchers were frustrated by the loss of physicality and increased dependence upon archival theory's social hierarchies in online searches. In virtual group discussions about their research practice, they expressed concerns about the increased policing effect that public health precautions like restricted access to special collections may have on black and brown people. Their perseverance through the pilot phase, however, also offers an opportunity for archivists and special collections librarians trying to find improvisational, creative solutions to a public health and public history crisis.
\end{abstract}

Too many times, archival institutions only exist outside of our communities. They cloister our stories away behind restrictions and structures intended to protect material.

But the reality is that these structures keep those records inaccessible to the very communities at the center of the narrative-a narrative we need to transform society. ${ }^{1}$ - Helyx Horwitz

1. Helyx Horwitz, "The People's Media Record Safeguards the Past While Making It Radically Accessible," Generosity, November 21, 2019, https:/ / generocity.org/philly/2019/11/21/the-peoples-mediarecord-safeguards-the-past-while-making-it-radically-accessible/. 
These words by Helyx Horwitz, Information Systems and Technology Manager at the Philadelphia-based Movement Alliance Project, were published in November 2019. Horwitz's words resonated then, but they stung in September 2020, six months into working through a global pandemic that has forced varying degrees of closure among archival institutions - and just when we hoped that the project I had been leading for the past two years would have begun expanding community access to archives.

I am the project director for Chronicling Resistance. Initiated by the Philadelphia Area Consortium of Special Collections Libraries (PACSCL) with funding from the Pew Center for Arts \& Heritage (PCAH) in 2018, Chronicling Resistance has had two chief aims: to amplify stories of resistance in the archives and to help collect and preserve stories of today's acts of resistance. ${ }^{2}$

Since the project's earliest stages, amplification has meant "giving voice to resistance-historical and current-in ways our institutions historically have not."” Librarians and archivists at PACSCL member institutions were aware in writing a funding proposal for Chronicling Resistance that reading rooms historically are far more likely to be populated by academics than they are by the general public and that the "general" public that frequents the archives also tends to be largely composed of a select few: donors and history hobbyists who skew towards being white, of expected retirement age, and wealthy. This "general" population also reflects the demographics of those people who founded most of our institutions, whose stories have since been prioritized in collection efforts, and hence who have been venerated in historical research and public memory of history, heroism, agency, and activism. As PACSCL's board wrote in its proposal to PCAH:

The collections of PACSCL members document three centuries of resistance-political, social, artistic, religious, or scientific.... Resistance is embedded in Philadelphia's DNA; the city and Pennsylvania colony were founded as an act of resistance to England's established religion, while European settlement was the subject of resistance by indigenous peoples. The historical and cultural materials preserved in libraries and archives may tell these stories - and others about labor resistance, women's suffrage, civil rights, and more-but are either not known or not available to everyone. ${ }^{4}$

2. Since July 2020, Chronicling Resistance has been housed at the Free Library of Philadelphia with primary funding from the Andrew W. Mellon Foundation and additional funding from the Pew Center for Arts \& Heritage.

3. Philadelphia Area Consortium of Special Collections Libraries, grant proposal to Pew Center for Arts \& Heritage (2017), in the author's possession.

4. Ibid. 
So, while our institutions have given voice to resistance, we have not always done so in ways that have let the working class-women; black, indigenous, and other people of color; people with disabilities; and people who identify as lesbian, gay, bisexual, transgender, or queer/LGBTQ+- know our materials exist. We have not always provided wider access to the materials, made people in these groups feel welcome in our spaces, or conducted programming that resonates with them or makes their connection to Philadelphia's and America's heritage meaningful to them. Also, through our collection priorities, we have not always let these groups know the importance of their stories to the historical record.

Silences are found in erasure, omission, and alienation. In its discovery phase, Chronicling Resistance found evidence of all three forms, and these findings were not a surprise. PACSCL previously had been awarded funding to locate "hidden" collections-collections that were not accessible within member libraries. PACSCL board members also had been influenced by scholars such as Saidiya Hartman, Michelle Caswell, Samip Mallick, and Jarrett M. Drake. The weaknesses of traditional archives have been exposed since Hartman addressed the necessity for historians to imagine what cannot be reconstructed from archival documents due to the archives' limitations and to the practice of social hierarchies within special collections. ${ }^{5}$ The same year Hartman called for "critical fabulation," Caswell and Mallick founded the South Asian American Digital Archive to preserve documentation of South Asian Americans' histories in the United States. ${ }^{6}$ Caswell and Mallick have since found their community-based archive counters the "symbolic annihilation," or systemic erasure and diminishment of agency and importance, of South Asian Americans from the historical record, and counters the effects of symbolic annihilation on those communities. ${ }^{7}$ They argue that if "archives are to be true and meaningful reflections of the diversity of society instead of distorted funhouse mirrors that magnify privilege, then they must dispense with antiquated notions of whose history counts and make deliberate efforts to collect voices that have been marginalized by the mainstream." 8 Drake concurs that special collections libraries and archives "must confront their complicity in upholding patriarchy, white supremacy, and other structural inequalities." $\mathrm{He}$ also offers a pathway forward for those who are committed to documenting a more inclusive and accurate historical record: build trust through practicing allyship with the people at the center of resistance movements.

5. Saidiya Hartman, "Venus in Two Acts," Small Axe 12, no. 2 (2008).

6. Hartman, "Venus in Two Acts," 11-12.

7. Michelle Caswell, "Seeing Yourself in History: Community Archives and the Fight against Symbolic Annihilation,” Public Historian 36, no. 4 (November 2014): 26-37.

8. Caswell, "Seeing Yourself in History," 36.

9. Jarrett M. Drake, "Expanding \#ArchivesforBlackLives to Traditional Archival Repositories," On Archivy, June 27, 2016, https: / / medium.com/ on-archivy/ expanding-archivesforblacklives-to-traditionalarchival-repositories-b88641e2daf6. 
With the funder's encouragement to ask broad questions that would provide room to develop the project, we set out to answer the following questions:

- What unknown stories held in our collections could help flesh out a picture of broader resistance?

- What are compelling ways to create connections among our audiences and the region's rich heritage in ways that are meaningful to those audiences?

- How can we give voice to resistance-historical and current-in ways that our institutions historically have not?

- What are the best ways to communicate the stories our collections tell and to expand the stories told about resistance?

- How do we reshape collecting priorities and engage new partners so that our collections hold meaning now and in the future?

From July 2018 to June 2019, the project director, assistant, and steering committee conducted eight listening sessions (free public events that included panel discussions, film screenings, pop-up exhibits, or story circles and Q\&A or audience discussions). The sessions were held at archives, at a school, and at community hubs in various neighborhoods. We also hosted two focus groups with local individuals who identify as artists, activists, organizers, or cultural organizers. Internally, we held biweekly steering committee meetings and four meetings with Thinking Partner Consultants, including advisors with experience as teachers, community activists, cultural organizers, and historic site program directors. All but two Thinking Partners lived and worked in Philadelphia.

To each listening session, we invited as presenters people who already included postcustodial practices in their work or whose artistic/cultural organizing work centered the history of a specific person, culture, or place. In doing so, we witnessed how history is filtered through artists, writers, curators, other storytellers, and activists and how the audiences we wanted in our reading rooms were most likely to connect with history.

\section{Discovery Phase Findings}

In all of the listening sessions that included a panel presentation, panelists and/or the audience expressed the importance of collecting their communities' histories, preserving them and/or passing them down orally or in writing, and making them accessible, first and foremost, to their own communities. ${ }^{10}$

10. Summaries of listening sessions and meetings can be found at Philadelphia Area Consortium of Special Collections Libraries, Chronicling Resistance, http:// resistance.pacscl.org/blog. 
All the panelists but one were black or were other people of color. All but two were female or gender nonbinary. Several identify as queer. All identify with demographics that collections have, until recent years, ignored or undervalued. While academics whose research focuses on ethnic or women and gender studies continue to express frustration at the lack of archival evidence of these groups' experiences, critique the archives for this void, and encourage archivists to rectify this error through more targeted collections efforts, we have found that these communities express little interest in handing their stories to an institution. ${ }^{11}$ Reasons for hesitation include the need to remain hidden, the concern that their story will be misinterpreted in mainstream hands, and accessibility—all of which also affect their research in and experience with traditional archives and affect how stories of resistance are told or silenced.

For example, the listening session at William Way LGBT Community Center's Community Archiving Forum revealed that, "while participants expressed a desire for their stories to be preserved in traditional institutions, they also acknowledge a need for archivists to find ways to help people collect and preserve their histories / experiences in a safe way that does not incriminate them. People who identify as LGBTQ sometimes need to remain 'closeted."' The forum further discussed how archivists "trained in verification methods that can privilege men and heteronormativity" might be insensitive "to the original context of materials collected by the LGBTQ community." This insensitivity or need to preserve process over perspective can result in the silence of omission in traditional archives. ${ }^{12}$

One focus group participant who is a person of color said that "the power" of immersing oneself in primary source material "is to see it in a way that [a white archivist, historian, or scholar] never can or will, because the history has been so interpreted and so hidden already." Similar to the experiences of the LGBTQ community, this person found history can be diluted through methods professionals learn to verify, preserve, and interpret it. Interpretation for this individual means connecting the historical document "to things and stories that your grandmother told you that these folks don't know nothing about, or the ones who did know worked really hard to shut down the stories of people's empowerment, survival, and their traditional knowledge." This individual is describing erasure in interpretation. ${ }^{13}$

11. See, for example, Darius Bost, Evidence of Being: The Black Gay Cultural Renaissance and the Politics of Violence (Chicago, IL: University of Chicago Press, 2019).

12. This listening session followed the event, "Who Tells Your Story? An LGBTQ Community Archives Forum, http:/ / resistance.pacscl.org/2019/03/14/who-tells-your-story-lgbtq-communityarchives-forum-recap/.

13. Focus group transcript, June 11, 2019, Philadelphia Area Consortium of Special Collections Libraries. 
To put this participant's comments in a way that answers a few of our questions, PACSCL members can unearth more stories about resistance within our own archives, give voice to resistance in new ways, and find compelling ways to create meaningful connections for a wider audience by inviting new people to interpret the material. As scholars like Erica Armstrong Dunbar and Saidiya Hartman have demonstrated through their respective books, Never Caught: The Washingtons' Relentless Pursuit of Their Runaway Slave, Ona Judge (2017), and Wayward Lives, Beautiful Experiments: Intimate Histories of Social Upheaval (2019), interpretation can shift dramatically when researcher and subject are both from historically marginalized communities. At the Library Company of Philadelphia and Temple University's Urban Archives, Dunbar and Hartman found documents in which black women were presented as enslaved or as a social problem; but, in their interpretation, a voice of liberation and agency among black women in the eighteenth and early twentieth centuries emerges.

Here I must note the obvious: Hartman and Armstrong Dunbar begin their research with the solid foundation of knowing that special collections libraries exist. The discovery phase also revealed that the public connects the past to the present but doesn't necessarily connect the past to archives. This lesson was most apparent in the listening session following a tour of At These Crossroads: The Legacies of Frederick Douglass and W.E.B. DuBois, at the Free Library of Philadelphia's Parkway Central branch on the library's 2019 Community Day. The exhibition presented facsimiles of archival documents found in multiple PACSCL-member institutions. The demographics of the listening session audience was more varied than that of the focus groups or panelists, yet most people were unaware of these institutions' existence and were pleasantly surprised to learn they are also open to the public. They also expressed much enthusiasm at the idea of preserving their own documents and, in contrast to most of the focus group participants, inquired about the types of documents local archives are interested in collecting. Their interests suggested an inherent appeal in thinking of oneself or one's experiences as an important part of the historical narrative, even when you do not know how personal documents come to be elevated as historical.

The experience at this listening session also invites unanswerable questions. What stories have been lost because people did not know they were valuable? How might seeing one's existence as significant affect our daily choices? How might scholarship have differed with different stories collected? Hartman writes, "Every historian of the multitude, the dispossessed, the subaltern, and the enslaved is forced to grapple with the power and authority of the archive and the limits it sets on what can be known, whose perspective matters, and who is endowed with the gravity and authority of historical actor." ${ }^{14}$ How might preserving the voices of the multitude now change the future?

14. Saidiya Hartman, "A Note on Method," in Wayward Lives, Beautiful Experiments: Intimate Histories of Social Upheaval (New York, NY: W.W. Norton \& Company, 2019), xiii. 
I also have to note that Armstrong Dunbar and Hartman are scholars. They have university I.D. cards and email addresses. Even if they do not see themselves reflected in the portraiture decorating the walls of a traditional archive, reading rooms are accessible to them. If they experience alienation in the archive, they probably don't experience it the same way a nontraditional researcher and some of our listening session panelists would and have.

Rasheedah Phillips, Co-Founder of Community Futures Lab, created a communitybased archive for her neighborhood. Phillips said during the Women of Color in Time, Place, and History panel, "I live down the street from Temple, and [the archive] still doesn't feel accessible. I know it's there, but it doesn't feel like it's there for me to access. That's why for me, doing the Community Futures Lab project, I was very conscious about, how do I create an archive that feels accessible ...that doesn't go into a vault at Temple. But something that is really, physically accessible, in the community, somewhere you can walk in, feel welcome, don't need an I.D., don't need to go through security to access information about the history of your community." 15 Access helps break the silences imposed by alienation.

It's worth noting that Archives for Black Lives in Philadelphia and the John J. Wilcox Archives at William Way LGBT Community Center offered material resources, temporary storage space, and cataloguing and preservation expertise to Phillips's organization. Her goals were accomplished in partnership with trained archivists who understood community-based archiving needs. ${ }^{16}$

\section{0}

With all we had learned in the discovery phase, a small portion of which I've focused on here, we began designing the implementation phase of Chronicling Resistance. We envisioned a project that, through research, interpretation, and programs built by and with contemporary activists and the marginalized communities they represent, would offer the opportunity to begin to name and address institutional harms, broaden Philadelphia libraries' and archives' cultural audiences, and offer new perspectives on local resistance narratives.

15. Rasheeda Phillips, in conversation with Yolanda Wisher, Karina Puente, and the author, in "Uncovering Women of Color in Time, Place, and History," Education Center at Uncle Bobbie's, Philadelphia, PA, December 12, 2018.

16. In 2021, ArchivesSpace, an open source, web application for managing archives information, announced its Diversity Partnership, a three-year fellowship program to support community-based archives and other traditionally underrepresented groups. It will offer ArchivesSpace membership, hosting with a Registered Service Provider, training, and user and technical support. Based on findings from the discovery phase of Chronicling Resistance and early needs emerging in the implementation phase, more of such partnerships likely will arise out of this project. 
In February 2020, we received a grant from the Gladys Krieble Delmas Foundation to test and further ground this idea as we awaited word on full funding. For this interim or pilot phase, we contracted with three cultural organizers. Their assignment was to identify materials (documents, ephemera, rare books, and the like) from five to seven PACSCL institutions that applied directly to their area of activism or organizing and to discuss their findings with each other and with me. They were also asked to assess their experience and to assist me with planning for the project's future by identifying existing and potential risks, biases, shortfalls, and so on in Chronicling Resistance's existing and proposed process for activists as archival research fellows.

With interests in food justice and food sovereignty among black and indigenous peoples, black drill teams and the history of Juneteenth in North Philly, and the life of an extraordinary but elusive African American tap dancer named Louise Madison, the fellows (Charlyn Griffith-Oro, muthi reed, and Germaine Ingram, respectively) began conducting research at four PACSCL-member institutions.-

\section{Then came March. We all know what happened in March.}

Every institution we had sat in for hours on end during the second week of March suddenly was closed, but the fellows wanted to continue their work. We had to make a quick pivot to digital research, and the loss of information was difficult. None of the items we had intended to either begin looking through or return to were digitized. One archive does not have an online search portal (though it does have digitized finding aids). Passwords were needed to access an in-house database at another. An archive at a university library had made certain databases, such as historical issues of Philadelphia's flagship African American newspaper, The Philadelphia Tribune, normally available onsite only, accessible offsite-but only to university I.D. card holders. Meanwhile, JSTOR opened its floodgates, removing the need for university affiliation to research its articles. ${ }^{17}$

The fellows and I found solace and inspiration in secondary sources, in our home libraries, in the built environments surrounding us, and in defining our research questions. ${ }^{18}$ We had intended to meet in person regularly throughout this interim

17. The Library Company of Philadelphia was allowed to share passwords with Chronicling Resistance at the beginning of the pandemic but has not yet committed to continuing this access for duration of the pandemic. In late July 2020, the Free Library of Philadelphia expanded its ProQuest subscription to include ten distinguished historical African American newspapers, including the Tribune. Cardholders can access this database through any internet connection. See https://libwww.freelibrary.org/blog/ post $/ 4300$.

18. Shortly after their visit to Philadelphia City Archives, muthi reed took a scheduled trip to New Orleans to visit family and decided to shelter in place there. Near the end of March, Charlyn GriffithOro initiated a bicoastal life, moving with their spouse to California. Their food justice organizing work and co-operative remain in Philadelphia. 
period (originally planned for three months) and decided to keep this regular meeting to find some stability and routine as the pandemic changed all of our lives.

We held these research check-ins biweekly, via Zoom, and shared our challenges, discoveries, and surprises as we navigated online research during a pandemic. The fellows suggested editing these conversations into a podcast that could also serve as a nontraditional research guide. The Delmas Foundation agreed, and the podcast, Research Revelations, streamed 13 episodes between July and October 2020. ${ }^{19}$

The fellows and I discuss a broad range of topics in the podcast, but for the purposes of this paper, I will highlight just a few and will also incorporate reflections the fellows sent to me in writing following our last virtual check-in. First, the loss of physicality. muthi reed was able to make only a few hours-long visits to City Archives before the closures and reported that, while "the time [there] didn't yield what I thought it would ...the time spent meandering yielded more nuanced questions about my research area." In searching Temple SCRC's online research portal, reed found the items they needed were not digitized, and they were able to see only the abstracts of news and journal articles. As they said, "the physicality of the work is definitely missed." ${ }^{20}$

For Germaine Ingram, "a key frustration" in online research was "the loss of the physical experience - the inability to open the boxes, turn the pages, run my finger down an inventory, to smell the age of an item." ${ }^{21}$ Ingram also noted the diminished spontaneity of online research. In the same way you can find a book you didn't know you were looking for by walking through the stacks toward your targeted item, you can also find surprises in an archival box. In online searches, however, "[w]e are more dependent on someone else's word logic or classifications, since there is less opportunity to root around in the archival neighborhood." I invite you to consider Ingram's statement with the following statement from Archives for Black Lives in Philadelphia's statement of principles: "Archival theory is rooted in concepts like provenance that promote social hierarchy and privilege document-creators (those who have the means to create and preserve records) over subjects." ${ }^{22}$ Now consider whose words a researcher is forced to be more dependent on when conducting archival research online. Whose silences grow, even when the researcher is someone who can bring new insight to the material?

\footnotetext{
19. See http://soundcloud.com/pacscl.

20. muthi reed, email to the author, June 12, 2020.

21. Germaine Ingram, email to the author, June 9, 2020.

22. Archives for Black Lives in Philadelphia, "Statement of Principles," January 9, 2017, https:// github.com/a4blip/A4BLiP.
} 
Enhanced silence also challenges Charlyn Griffith-Oro in the archives, though their difficulties exist both in physical and virtual spaces:

My greatest frustration is the challenge that I also have with old literature ....in general: because of white supremacy and the fact that American history began with the brutality of the theft of indigenous land along with the Trans-Atlantic Slave Trade, it is increasingly difficult to believe anything I find in the collections. Each and every piece of writing is full of the bias of that writer's experience of racism, classicism, imperialism. It gets difficult to connect to a piece without criticism. At times it feels lonely. ${ }^{23}$

While physical contact with the material would not alleviate their frustrations, Griffith-Oro's issues with the biases present in how archives are organized are played out in Ingram's experience with online searches. The loss of physicality magnifies the bias; reducing or eliminating it may require frequent revisions to finding aids or unusual partnerships in which a donor or community at the center of the material provides language for the finding aid.

Another topic that emerged from the podcast conversations was the danger of heightened policing. Let's revisit the opening words from Helyx Horwitz: "[Archival institutions] cloister our stories away behind restrictions and structures intended to protect material." Horwitz suggests that, in archival institutions, people, their need to know their own history, and the transformation of society have a lower priority than the posterity of historical material. But we have entered an ironic time in which restrictions to material have or will be increased to protect people, even as those public health measures further alienate traditionally marginalized groups.

Josue Hurtado, an archivist and research librarian, and Coordinator of Public Services at Temple Special Collections Research Center, joined one of our research check-ins in May 2020. Throughout his career, Hurtado has championed increasing access to the archives, and he was open about the ways limiting hours, the number of people who can be in one space at a time, and the number of hands that can touch physical material each week affects that access. "All this stuff kills me, because my whole career I've been trying to take down some of these barriers to access." ${ }^{24} \mathrm{He}$ has advocated, for example, for an end to I.D. requirements for researchers, something he indicated universities located in working-class or im-

23. Charlyn Griffith-Oro, email to the author, June 23, 2020.

24. Philadelphia Area Consortium of Special Collections Libraries (PACSCL), "10.0 Legitimizing Existence, Power, and Enduring Value," September 24, 2020, in Research Revelations, produced by Mariam Williams and Ann McShane, MP3 Audio, 20:29, https://soundcloud.com/pacscl/legitimizing-existencepower-and-enduring-value. 
poverished black and brown neighborhoods may be especially resistant to do, even though, as Griffith-Oro pointed out, black and brown students and community members "tend to get the brunt of people's heightened anxiety around policing." 25 Complicating matters is how the coronavirus shifts such decisions about accessibility further away from archivists. When Hurtado spoke with us, the Department of Health and the Temple University School of Medicine also were involved in determining best practices for research visits and handling materials. "But I think there are some good [public health] safety reasons as to why we're going to have to implement [more restrictions], as unpleasant as I think it is to have to lock some of this away." ${ }^{26}$ While most archivists are not in a position to set university decisions, they can be accomplices with and allies to the surrounding community by acknowledging black and brown communities' concerns about policing, bringing those concerns to their supervisors and directors, and applying safety protocols equally, rather than selectively.

Finally, I want to highlight the ways in which unexpected restrictions sometimes make room for us to get creative. As previously stated, the fellows investigated their own libraries in the absence of being able to be physically present in the archives. In this way, Ingram located an article discussing improvisation in art-based research. ${ }^{27}$ Among Ingram's conclusions from that article and an improvisational movement workshop by KJ Holmes that Ingram, a dancer herself, had been attending virtually, were these statements: "Improvisation, when done well, ... represents a way of knowing, a willingness to embrace uncertainty," and, "Being where you are when you don't know where you are is the most precious spot provided by improvisation." 28

Ingram found the ideas she paraphrased for us to be "potent ... but challenging" in this time of "not-knowing" that we live in, and I concur. ${ }^{29}$ While the world will be different by the time this article is published, in September 2020 we were here:

25. PACSCL, "10.0 Legitimizing Existence, Power, and Enduring Value"; lawsuits filed by African American Philadelphia residents against campus police over the last few years have resulted in increased scrutiny of privately run police departments that hold jurisdiction on and off Philadelphia area campuses. Temple University has the largest university police department in the country. See WHYY, "Why does the power of campus police go unchecked?" The WHY, May 13, 2019, https: / / whyy.org/episodes/ why-does-the-power-of-campus-police-go-unchecked/; and Ryan Briggs, "Secretive Campus Cops Police Already Overpoliced Neighborhoods," The Appeal, October 15, 2018, https:/ theappeal.org/secretivecampus-cops-patrol-already-over-policed-neighborhoods/.

26. Josue Hurtado, Philadelphia Area Consortium of Special Collections Libraries, "10.0 Legitimizing Existence, Power, and Enduring Value," September 24, 2020, in Research Revelations.

27. Nisha Sajnani, "Improvisation and Art-Based Research," Journal of Applied Arts \& Health 3, no. 1 (2012): 79-86.

28. Philadelphia Area Consortium of Special Collections Libraries (PACSCL), "8.0 Improvisations and Composites," September 11, 2020, in Research Revelations, produced by Mariam Williams and Ann McShane, MP3 Audio, 18:09, https://soundcloud.com/pacscl/improvisations-and-composites.

29. PACSCL, "8.0 Improvisations and Composites." 
in the age of COVID-19, closures, and decreased access to primary sources; in the delayed beginning of a research project intended to break silences in the archives and expand historical interpretation; in a time when the President of the United States contends that history should never be reexamined-especially not from the lenses of Black or indigenous people; and when institutions who make statements of solidarity with people fighting for social justice will have moments of hypocrisy exposed. ${ }^{30}$ This was a place we had never been before, and we had no choice but to be here.

And as Ingram noted, it is a compelling challenge to live in uncertainty, embrace it, and also "make it a place of discovery." ${ }^{31}$ It is also an opportunity. To summarize Hurtado, traditional archives have long reflected the society we live in by legitimizing and delegitimizing existences, power, and enduring value. ${ }^{32}$ But as we continue to find where we are in the pandemic, we can still discover ways to make our institutions tools for societal transformation.

\footnotetext{
30. Howard Zinn, noted historian and author of A People's History of the United States (New York, NY: Harper Collins, 1980), and the New York Times' Pulitzer Prize-winning series, The 1619 Project (2019), anchor the founding of the United States to the oppression of indigenous peoples and enslaved Africans, respectively. In his remarks at the White House Conference on American History, President Donald Trump cited Zinn's works and the 1619 Project as examples of "propaganda tracks" that have "warped, distorted, and defiled the American story with deceptions, falsehoods, and lies." He also called the teaching of Critical Race Theory "child abuse" and announced plans to establish the "1776 Commission," "a national commission to promote patriotic education." See Rev, "Donald Trump's remarks at the White House Conference on American History," transcript, Rev.com, September 17, 2020, https:/ / www.rev. $\mathrm{com} / \mathrm{blog} /$ transcripts / donald-trump-speech-transcript-september-17-white-house-history-conference. Aisha Harris, “'This You?’ (It Definitely Is),” New York Times, June 9, 2020, https:/ / www.nytimes. com/2020/06/09/opinion/this-you-black-twitter.html.

31. Philadelphia Area Consortium of Special Collections Libraries, "8.0 Improvisations and Composites," September 11, 2020.

32. Josue Hurtado, Philadelphia Area Consortium of Special Collections Libraries, "10.0 Legitimizing Existence, Power, and Enduring Value," September 24, 2020, in Research Revelations.
}

\section{INDEX TO ADVERTISERS}

Atlas Systems cover 2

Bruce McKittrick Rare Books...................................................... 1

Kelmscott Bookshop ................................................................... 7

Priscilla Juvelis Rare Books................................................ cover 4

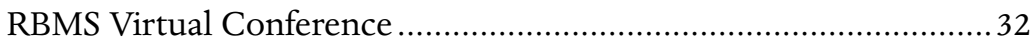

Rulon-Miller Books ........................................................................ 4

Swann Galleries ................................................................... cover 3 